\title{
Quantifying rice yield gaps and their causes in Eastern and Southern Africa
}

K. Senthilkumar ${ }^{*}$, J. Rodenburg ${ }^{2}$, I. Dieng ${ }^{3}$, E. Vandamme ${ }^{4}$, F.S. Sillo ${ }^{5}$, J-M. Johnson ${ }^{6}$, A. Rajaona $^{1}$, J.A. Ramarolahy ${ }^{1}$, R. Gasore ${ }^{7}$, B.A. Bayuh ${ }^{8}$, G.J. Kajiru9 ${ }^{9}$ J. Mghase ${ }^{10}$, J. Lamo ${ }^{11}$, R. Rabeson ${ }^{12}$, K. Saito ${ }^{3}$

${ }^{1}$ Africa Rice Center (AfricaRice), P.O. Box 1690, Antananarivo, Madagascar; ${ }^{2}$ Natural Resources Institute (NRI), University of Greenwich, Chatham Maritime, Kent, ME4 4TB, UK; ${ }^{3}$ Africa Rice Center (AfricaRice), 01 B.P. 2551, Bouaké 01, Côte d'Ivoire ; ${ }^{4}$ International Potato Center (CIP), P.O. Box 1269, Kigali, Rwanda; ${ }^{5}$ Africa Rice Center (AfricaRice), P.O. Box 33581, Dar es Salaam, Tanzania; ${ }^{6}$ Institute of Crop Science and Resource Conservation (INRES), University of Bonn, D-53115 Bonn, Germany ${ }^{7}$ Rwanda Agricultural Board (RAB), P.O Box 5016, Kigali, Rwanda; ${ }^{8}$ Ethiopian Institute of Agricultural Research (EIAR), P.O. Box 1745, Bahir Dar, Ethiopia; ${ }^{9}$ Department of Research and Development, Ministry of Agriculture, P.O. Box 2066, Dar es Salaam, Tanzania; ${ }^{10}$ Kilombero Agricultural Research and Training Institute (KATRIN), P.O. Box 405, Ifakara, Tanzania; ${ }^{11}$ National Agricultural Research Organization (NARO), Mbale, Uganda; ${ }^{12}$ Centre National de Recherche Appliquée au Développement Rural (FOFIFA), Antananarivo, Madagascar

\begin{abstract}
The demand for rice in Eastern and Southern Africa is rapidly increasing because of changes in consumer preferences and urbanization. However, local rice production lags behind consumption, mainly due to low yield levels. In order to set priorities for research and development aimed at improving rice productivity, there is a need to characterize the rice production environments, to quantify rice yield gaps - i.e. the difference between average on-farm yield and the best farmers' yield — and to identify causes of yield gaps. Such information will help identifying and targeting technologies to alleviate the main constraints, and consequently to reduce existing yield gaps. Yield gap surveys were conducted on 357 rice farms at eight sites (19-50 farmers per site) across five rice-producing countries in Eastern and Southern Africa - i.e. Ethiopia, Madagascar, Rwanda, Tanzania and Ugandafor one or two years (2012-13) to collect both quantitative and qualitative data at field and farm level. Average farm yields measured at the eight sites ranged from 1.8 to $4.3 \mathrm{tha}^{-1}$ and the average yield gap ranged from 0.8 to $3.4 \mathrm{t} \mathrm{ha}^{-1}$. Across rice growing environments, major causes for yield variability were straw management, weeding frequency, growth duration of the variety, weed cover, fertilizer (mineral and organic) application frequency, levelling and iron toxicity. Land levelling increased the yield by $0.74 \mathrm{t} \mathrm{ha}^{-1}$, bird control increased the yield by $1.44 \mathrm{t} \mathrm{ha}^{-1}$, and sub-optimal management of weeds reduced the yield by 3.6 to $4.4 \mathrm{t}$ $\mathrm{ha}^{-1}$. There is great potential to reduce the current rice yield gap in ESA, by focusing on improvements of those crop management practices that address the main site-specific causes for suboptimal yields.
\end{abstract}

KEYWORDS: smallholder farmer; weeds; birds; yield variability; irrigated lowland; rainfed lowland; upland.

\footnotetext{
**Correspondence: K. Senthilkumar; E-mail: k.senthilkumar@cgiar.org
} 


\section{INTRODUCTION}

Demands for rice in Eastern and Southern Africa (ESA) are rapidly increasing because of changes in consumer preferences and urbanization (Balasubramanian, Sie, Hijmans, \& Otsuka, 2007; FAO, 2018). However, local rice production lags behind consumption, and this is mainly due to the low yield levels attained on smallholder farms (Senthilkumar, Tesha, Mghase, \& Rodenburg, 2018; van Ittersum et al., 2016; van Oort et al., 2015). Low rice yield levels at African smallholder farms are caused by abiotic stresses such as drought, nutrient deficiencies and/or toxicity, cold and heat (Haefele et al., 2013; Kijoji et al., 2012; Nhamo et al., 2014; Poussin et al., 2003; Saito et al., 2019, 2015, 2013; Tanaka et al., 2017) and biotic stresses such as birds (De Mey, Demont, \& Diagne, 2012), insect pests, diseases and weeds (Adesina, Johnson, \& Heinrichs, 1994; Diagne et al., 2013; Rodenburg \& Johnson, 2009; Rodenburg et al., 2019). The sub-optimal crop management practices followed by rice farmers in this region only sustain or aggravate this situation (Saito et al., 2013; Senthilkumar et al., 2018; Tanaka, Saito, Azoma, \& Kobayashi, 2013).

While the prime aim of many governments in sub-Saharan Africa (SSA) is to achieve rice self-sufficiency, the average sufficiency rate is only 60\% (CARD, 2018; Saito et al., 2015). In order to increase self-sufficiency rates in SSA, research and development efforts are needed to identify and address the main production constraints. To this end, so-called Rice Sector Development Hubs (hereafter called 'sites') were established through stakeholder consultation workshops in more than 20 countries across Africa in 2012 (AfricaRice, 2011). These sites are of strategic importance for the national rice sectors of these countries.

For site-specific priority setting of research and development efforts, there is a need to characterize the rice production environments, quantify gaps between average on-farm yield and the best farmers' yield (also known as 'farmer-based yield gaps'; henceforward referred to as 'yield gaps') and identify their main causes in each country (Saito et al., 2017). Previous analyses of data obtained from these sites focused on the continental level (Rodenburg et al., 2019; Tanaka et al., 2017) and the West African regional level (Niang et al., 2017). Detailed site and production environment specific analysis are currently lacking for Eastern and Southern Africa. Such information is essential for developing site-specific or field-specific recommendations on crop and nutrient management practices. Following successful piloting of a web-based decision support tool for nutrient management in Senegal (Saito et al., 2015), an android based applications "RiceAdvice" and "RiceAdvice-WeedManager" were developed by the Africa Rice Center (AfricaRice), and "RiceAdvice" was validated and disseminated in several countries in West Africa (Saito and Sharma, 2018). This study reported here are aimed to provide with information on current farmers' practices and identify key intervention areas for developing or improving these applications specific to East and Southern African countries.

The objectives of this study were to: 1) quantify the current rice yield levels and yield gaps, 2) characterize the current production factors followed by farmers, 3 ) identify production factors causing the yield variability and 4) quantify their degree of influence at the site and production environment level in East and Southern Africa.

\section{MATERIALS AND METHODS}

\subsection{Study sites and yield gap survey}

This study was conducted in eight sites across five ESA countries (i.e. Tanzania, Uganda, Ethiopia, Rwanda and Madagascar; Figure 1 \& Table 1). Each site represents a key rice production environment i.e. irrigated lowland (IL), rainfed lowland (RL) or rainfed upland (RU). There were four sites under IL, three sites under RL and one site under RU. All the villages within a site were listed and five villages in the first year and another two villages 
were selected randomly for the on-farm yield gap surveys (YGS). From these selected villages, a minimum of 19 to a maximum of 50 farmers' fields were randomly identified and surveyed for the entire duration of the main cropping season for one or two years (Table 1). The YGS were conducted using a standardized protocol at all sites between 2012 and 2013. A total of 357 farmers' fields were surveyed, 168 in 2012 and 189 in 2013. The number of fields surveyed for each production environment was 128 in irrigated lowland, 186 in rainfed lowland and 43 in rainfed upland.

\subsection{Data collection}

Within each farmer's field, a survey plot of $200 \mathrm{~m}^{2}$ was established at the beginning of the season. Within each of these survey plots, three $12 \mathrm{~m}^{2}$ harvesting areas were delineated for observations on crop management practices followed by the farmer and for the final yield assessment. The grain yields from these three harvesting areas were weighted using a crane scale, and adjusted to $14 \%$ moisture content, using a digital grain moisture meter (Model SS7; Satake Eng. Co., Tokyo, Japan), and averaged for final yield estimation of the survey plot. Information on farmers' agricultural practices were collected through field observations at the time of field visits and farmer interviews. Practices included land preparation (i.e. tillage, bunding and levelling), crop residue management (i.e. straw removal from the field, burning, animal feeding, mulching or incorporation into the soil in the field), varieties (i.e. traditional or modern [see: Zenna, Senthilkumar, \& Sie, 2017; Prasad, Shivay, $\&$ Kumar, 2017], growth duration of the variety), crop establishment method (i.e. transplanting or direct seeding), fertilizer management (i.e. quantity and frequency of organic and/or mineral fertilizer application) and crop protection measures (i.e. frequency of weeding operations, bird and rat control). The weed infestation level above and below the rice canopy was visually assessed half-way the cropping season, following the procedure of Savary and Castilla (2009). Iron toxicity was assessed and visually scored over four categories (i.e. no toxicity, mild, moderate and severe) following standard protocols (Audebert \& Fofana, 2009; Becker \& Asch, 2005; Onaga, Egdane, Edema, \& Abdelbagi, 2013).

\subsection{Statistical analysis}

Yield gaps in this study refer to the difference between actual and attainable yield, whereby actual yield was calculated as the overall mean farmers' yield and attainable yield was calculated as the mean of the top-10 percentile farmers' yield for each site and production environment combination. This is a robust approach as it prevents errors caused by singlefield yield outliers (Tanaka et al., 2017) and it considers the local bio-physical and socioeconomic conditions (Stuart et al., 2016). To describe and characterize the rice production practices, the number of observations of a production practice was expressed in percentages at both the site and the production environment level. To simplify the characterization, for sites with two observation years (i.e. in Madagascar and Tanzania) data of both years were combined.

Random Forests procedures were used to identify the most important production factors, in decreasing order of importance, that caused the yield variability at each site and production environment level per year. Random forests are an ensemble of techniques for classification and regression with the use of multiple decision trees introduced by Breiman (2001). Each of the trees is built using a sample of the data, and at each split the candidate set of variables is a random subset of the variables. The mean decrease in accuracy is calculated to assess for variable importance: for each tree, the Mean Squared Error is recorded; then the same is done after permuting each predictor variable; the difference between the two are then averaged over all trees and normalized by the standard deviation of the differences. The important production factors identified were further subjected to multiple regression analysis 
to quantify their degree of influence - i.e. yield increase or decrease as a function of a given production practice compared to the reference practice - on yield variability. Only statistically significant results are presented. All analyses were done using R software, Version 3.5.1 (R Development Core Team, 2018) for all sites.

\section{RESULTS AND DISCUSSION}

\subsection{Rice yield and yield gap}

Across sites, irrigated lowlands registered an average yield of 3.1 to $3.5 \mathrm{t} \mathrm{ha}^{-1}$ with a yield gap of 2.0 to $3.3 \mathrm{tha}^{-1}$. Similarly, across rainfed lowlands the average yield ranged from 3.1 to $3.5 \mathrm{t} \mathrm{ha}^{-1}$ with a yield gap of 3.1 to $3.3 \mathrm{tha}^{-1}$. The rainfed uplands registered lower sitespecific average yields, i.e. 1.8 to $2.7 \mathrm{t} \mathrm{ha}^{-1}$ and a smaller absolute yield gap, i.e. 1.3 to $1.8 \mathrm{t}$ $\mathrm{ha}^{-1}$ (Figure 2a). At the production environment level there is no large difference in yields and yield gaps in ESA and those in West Africa (Niang et al., 2017) or the wider region, SSA (Tanaka et al., 2017). The yields in RU in ESA are lower compared to IL and RL due to persisting production constraints such as drought (Defoer et al., 2004; Dramé, Manneh, \& Ismail, 2013), low soil quality (Bruelle et al., 2014; S. M. Haefele, Nelson, \& Hijmans, 2014), higher weed infestation (Rodenburg \& Johnson, 2009) including the parasitic weed Striga asiatica (Rodenburg, Demont, Zwart, \& Bastiaans, 2016), cold stress and blast (Raboin et al., 2014).

Across production environments, the average yield ranged from 1.8 to $4.3 \mathrm{tha}^{-1}$ for the eight sites in ESA (Figure 2b). The irrigated lowland site 'Ambohibary' in Madagascar registered the highest mean yield in both years ( 3.9 to $4.3 \mathrm{t} \mathrm{ha}^{-1}$ ), followed by the rainfed lowland sites 'Kahama' in Tanzania (3.8 $\mathrm{t} \mathrm{ha}^{-1}$ in 2013) and 'Fogera' in Ethiopia (3.6 $\mathrm{t} \mathrm{ha}^{-1}$ in 2012). The lowest yield was registered for the rainfed upland site 'Ankazomiriotra' in Madagascar (1.8 $\mathrm{t} \mathrm{ha}^{-1}$ in 2012). Observed mean yield levels are similar to the regional yield levels of 4.0, 2.6 and $1.6 \mathrm{tha}^{-1}$ for the irrigated lowland, rainfed lowland and upland production environments, respectively (Saito et al., 2017; Tanaka et al., 2017) and the subregional (West Africa) yield levels (Niang et al., 2017).

Across environments, the rice yield gap ranged from 0.8 to $3.4 \mathrm{tha}^{-1}$ which is equivalent to a minimum of $21 \%$ and a maximum of $131 \%$ of the mean yield estimated across sites (Figure 2b). This implies that there is a high potential to increase yields. In theory this could be achieved by shifting from common cultivation practices to practices followed by the farmers who achieved the highest yield in each site. The highest yield gap (i.e. 3.4 and $3.3 \mathrm{t} \mathrm{ha}^{-1}$ ) was observed in 'Kilombero' in Tanzania and 'Doho' in Uganda, respectively. Among the three sites where the YGS was conducted for two consecutive years, the mean yield and yield gap were consistent at the irrigated lowland site 'Ambohibary' but highly variable at the rainfed lowland site 'Kahama' and the upland site 'Ankazomiriotra'. Yield variability across years in the rainfed sites could be caused by the variability of soil/flood water status resulting from annual rainfall variability. This is commonly observed in rainfed rice environments in SSA (Niang et al., 2018).

\subsection{Rice production practices in ESA}

The field observations and interviews revealed that rice straw from the previous season was removed from the field by $>60 \%$ farmers in five sites (Table 2). It was burnt in four of the eight sites, but only by a substantial share of farmers (69 and $25 \%$; respectively) in Kilombero (Tanzania) and Doho (Uganda). Straw burning has been reported all around the world (Affholder, Poeydebat, Corbeels, Scopel, \& Tittonell, 2012; Akanvou et al., 2000; Dobermann \& Fairhurst, 2000; Matsumoto, Paisancharoen, \& Ando, 2010; Sheldrick, Syers, \& Lingard, 2002) and ESA sites are not different in this regard. At seven of the eight sites, 
farmers (ranging from 4 to $32 \%$ ) incorporated the straw in the soil. At only three sites farmers (3-9\%) used straw as mulch in the field. Overall, five sites have straw removal and one site each have burning, animal feeding, and incorporation in the soil as dominant practice. The highest share of farmers practising rice straw mulching was observed in the rainfed upland site Ankazomiriotra in Madagascar where this is one of the management practices of the Conservation Agriculture approach promoted by local agricultural research and extension organisations and projects (Corbeels et al., 2014).

Tillage methods were observed to contrast largely between sites. In the sites in Rwanda, farmers conducted soil tillage only manually (hand hoes), while in Kahama (Tanzania) and Fogera (Ethiopia) only animal traction was used. The complete reliance on manual tillage in Rwanda was also observed in a recent study on weed management practices in rice in sub-Saharan Africa (Rodenburg et al., 2019). Both animal-driven and manual tillage were practiced in Madagascar and Uganda. Mechanical tillage, using a tractor, was only practised in Kilombero (Tanzania), by $76 \%$ of the farmers.

In all lowland sites, except the rainfed lowland site Kilombero (Tanzania), bunding of rice fields was observed (Table 2). In the rainfed upland site Ankazomiriotra (Madagascar), only few farmers $(7 \%)$ bunded their field. Well-levelled rice fields were observed in Ambohibary (Madagascar; 98\%) and Doho (Uganda; 71\%). In all other sites, the fields were either poorly levelled or not levelled at all (Table 2). Regarding crop establishment methods, transplanting was practiced by all farmers in the irrigated lowland sites in Uganda and Rwanda; direct seeding was practiced by all in the rainfed lowland site in Ethiopia and the upland site in Madagascar. In all other sites either transplanting or direct seeding was practiced depending on the location of the field within the site. The above information could help to develop sitespecific good agricultural practices training material and fine-tune RiceAdvice on general crop management practices practiced in each site.

\subsection{Weeds}

Across the sites, only few fields ( 2 to $11 \%$, in six of eight sites) were completely weed free (Table 3). Soil coverage by weeds below the rice canopy was mostly below 30\%. More than $30 \%$ below-canopy weed coverage was mainly observed at the two sites of Tanzania (19 and $31 \%$ of the fields), at Doho (Uganda; 18\%) and Rwasave (Rwanda; 20\%). The estimated soil coverage of weeds above the rice canopy was relatively low at all sites (Table 3 ). The majority of farmers weeded their crop at least once during the season; only in three sites (Ambohibary: 2\%; Kahama: 8\%; Doho: 7\%) farmers were observed that did not weed at all (Table 3). Across sites, weeding frequency was generally between one and three times, confirming a recent report on weed management in rice across SSA countries (Rodenburg et al., 2019). In only four sites weeding frequencies above three were observed, and the share of farmers weeding three-time, or more was only substantial (70\% in Ambohibary) or fairly substantial (16\% in Ankazomiriotra) in Madagascar. Mechanical weed control using a rotary weeder (Johnson et al., 2018; Rodenburg et al., 2015) was used in $97 \%$ and $49 \%$ of the farmers in Madagascar (Ambohibary and Ankazomiriotra respectively), 28\% of the farmers in Kahama (Tanzania) and 50\% of the farmers in Doho (Uganda). Predominant use of rotary weeders in Madagascar and absence of mechanical weeding in Ethiopia and Rwanda has been reported recently (Rodenburg et al., 2019).

\subsection{Fertilizers}

Fertilizer use, both mineral and organic, was low at all sites except the two Rwandan sites (Table 4). No fertilizers were used by $46-76 \%$ of the farmers in five of the 8 sites. In Rwanda, $68-72 \%$ of the farmers used both mineral and organic fertilizers and nearly all other farmers used only mineral fertilizers. In all other sites only $0-21 \%$ of the farmers used both types of 
fertilizers. In the upland site of Madagascar, $77 \%$ of the farmers used only organic fertilizers. The amount of mineral fertilizer used per ha was also very low in all sites except the two Rwandan sites. The mean $\mathrm{N}$ application rate was between 22 and $45 \mathrm{~kg} \mathrm{ha}^{-1}$ in the two Rwandan sites while it was no more than $11 \mathrm{~kg} \mathrm{ha}^{-1}$ in other sites. Similarly, the mean P and $\mathrm{K}$ rates were between $21-25$ and $11-26 \mathrm{~kg} \mathrm{ha}^{-1}$ respectively in the Rwandan sites and did not surpass $4 \mathrm{~kg} \mathrm{ha}^{-1}$ at other sites (Table 4). Very little or no use of mineral fertilizers by smallholder rice farmers in SSA has been reported previously (Castellanos-Navarrete, Tittonell, Rufino, \& Giller, 2015; Cobo, Dercon, \& Cadisch, 2010; Stoorvogel \& Smaling, 1998; van Ittersum et al., 2016; Vandamme et al., 2018). A combination of suboptimal accessibility, affordability, risk and awareness of mineral fertilizer is the underlying cause of this limited use of fertilizer (Balasubramanian et al., 2007; Diagne, Demont, Seck, \& Diaw, 2012; Haefele et al., 2014; Nhamo et al., 2014; Saito et al., 2019). The relatively high use of mineral fertilizers in Rwanda, on the other side, was due to the government regulations promoting the use of mineral fertilizers for rice cultivation. Here, the fertilizers were supplied to individual farmers through farmers cooperatives (Verhofstadt \& Maertens, 2014). The above information on fertilizer use along with current yield levels could help to set the target yield boundaries in RiceAdvice in each site.

\subsection{Varieties, irrigation and drainage, biotic and abiotic constraints}

Traditional varieties were used in more than 50\% of surveyed fields in Tanzania and Uganda and almost in all fields in Ambohibary (Madagascar) and sites in Ethiopia and Rwanda (Table 5). Improved modern varieties such as NERICA-4, Primavera and B22 were used at Ankazomiriotra in Madagascar (88\%), variety Saro-5 at Kahama (13\%) and Kilombero $(38 \%)$ in Tanzania, and variety K98 at Doho (36\%) in Uganda. A recent study from Kilombero observed Kisekese, Kalamata and Super India to be among the most popular local varieties (Senthilkumar et al., 2018). The poor adoption rates of improved modern rice varieties in ESA has been attributed to the mismatch in terms of farmer and consumer grain quality preferences (Meertens, Ndege, \& Lupeja, 1999; Nhamo et al., 2014) and more recently to suboptimal adaptation to occurring climate extremes and poor performance following erratic crop management that is often observed at smallholder farms (Sekiya, Tomitaka, Oizumi, Assenga, \& Jacob, 2015).

Irrigation and drainage systems were available and operational in all the irrigated lowlands sites. Only at the rainfed lowland site of Ethiopia and the upland site of Madagascar drainage systems were available for 5 to $19 \%$ of the fields surveyed (Table 5).

Bird control measures were taken only at Doho in Uganda (93\%), at Fogera in Ethiopia (9\%) and at the two sites of Rwanda (28-50\%). Rat control measures were taken only at Doho (96\%) and to a lesser extent at the two sites in Madagascar (2-5\%) (data not shown). Severe iron toxicity symptoms were observed only at the two sites of Rwanda (72$92 \%$ fields surveyed), while no or only moderate symptoms were observed at other sites.

\subsection{Causes of rice yield variability}

Through the random forests procedure, the top-five most important crop production factors that caused the yield variability in each site and production environment per year, were identified (Table 6). At the ESA regional level, the most important crop management practices causing yield variability were straw management, weeding frequency, duration of the variety, weed cover above and below rice canopy, fertilizer (mineral and organic) application frequency, land levelling and iron toxicity as they appeared most often across the study sites (Table 6). The above-mentioned factors are often cited among the most important yield limiting and reducing factors across field crops (Lobell, Cassman, \& Field, 2009; Poussin et al., 2003; van Ittersum \& Rabbinge, 1997). However, the yield variability causes 
were site and production environment specific, as presented in Table 6 . For instance, at Ambohibary (Madagascar) differences in weeding frequency, weed presence in above and below rice canopy, tillage method, crop duration and crop establishment method were identified as the main causes for the yield variability across the surveyed farmers' fields. At Ankazomiriotra (Madagascar), straw management, weeds below and above rice canopy and mineral fertilizer (nitrogen) application are the main causes for the yield variability. Other site-specific factors causing yield variability were bird control (at Fogera in Ethiopia and Doho in Uganda) and iron toxicity (at Kilombero in Tanzania and both sites in Rwanda) as presented in Table 6 .

Analysis per production environment and year showed that straw management, crop duration, organic fertilizer application, presence of weeds and weeding frequency and iron toxicity were the most important factors causing yield variability in irrigated lowlands. In rainfed lowlands, tillage and crop establishment method, weeds and weeding frequency are the most important factors. In rainfed uplands straw management, mineral fertilizer (mainly $\mathrm{N})$ application, crop duration, presence of weeds and weeding frequency are the top most important production practices causing yield variability. Most of the above factors were also reported as the main causes of yield variability across the three production environments in West Africa (Niang et al., 2017; Poussin et al., 2003). However, soil, cropping system and weather parameters were not considered in this study and further studies are needed including these factors.

\subsection{Degree of influence of production practices on yield}

Multiple linear regression analysis revealed factors with a high degree of influence on rice yield per site. Extending the crop duration by one day increased the yield by $0.05 \mathrm{tha}^{-1}$ and protecting the crop from grain feeding birds increased the yield by $1.44 \mathrm{t} \mathrm{ha}^{-1}$ in Fogera, Ethiopia (Table 7). These results confirm previous studies showing that long duration crops yield higher than short duration crops (Balasubramanian et al., 2007; Dingkuhn \& Asch, 1999) and bird damage is one of the major rice-yield reducing factors in SSA (Adesina et al., 1994; De Mey, Demont, \& Diagne, 2012). Season-long exposure to birds may cause rice yield losses between 13 and 95\% (Rodenburg et al., 2014).

At Kahama in Tanzania good land levelling increased the yield by $0.74 \mathrm{t} \mathrm{ha}^{-1}$ compared to the unlevelled fields. At Kilombero in Tanzania, compared to the weed-free fields, presence of a below canopy weed cover ranging from less than 10 to more than $60 \%$ reduced the yield by 3.6 to $4.4 \mathrm{tha}^{-1}$. Good land levelling and timely weed control are components of good agricultural practices recommended to avoid yield losses (Rodenburg \& Johnson, 2009; Senthilkumar et al., 2018). In the irrigated lowland of Ambohibary, compared to direct seeding, yield reduced with $1.74 \mathrm{t} \mathrm{ha}^{-1}$ by transplanting. A likely reason for this discrepancy, is that these fields were positioned relatively high along the upland-lowland continuum and were therefore unflooded for most of the growing season. Direct seeding in well-drained soils has been proven previously to be beneficial for rice growth and yield (Bouman, Humphreys, Tuong, \& Barker, 2007; Nie et al., 2012; Senthilkumar, Bindraban, Thiyagarajan, de Ridder, $\&$ Giller, 2008; Thiyagarajan et al., 2002). In addition, these higher topographic positions were previously used for off-season vegetable production with mineral fertilizer inputs (Raymond Rabeson, Agronomist/Soil Scientist, Head of Department of Rice Research, FOFIFA, $14^{\text {th }}$ September 2019, personal communication), the carry-over effects which could contribute to the observed yield increase. In both irrigated lowland sites of Rwanda, straw incorporation from the previous season reduced the yields in the following season by 1.38 to $1.57 \mathrm{t} \mathrm{ha}^{-1}$. This yield drop could be caused by temporary immobilization of nutrients mainly $\mathrm{N}$ in the soil following straw incorporation compared to straw removal or burning, however there may be long-term benefits on yield (Dobermann \& Fairhurst, 2000). Furthermore, the 
time available for decomposition of straw and consequently the release of additional nutrients was too short at these sites due to the high altitude ( $>1500 \mathrm{~m}$ a.s.1.), with relative low temperatures, and because two crops of rice were grown successively in one year. There could be other reasons for the yield drop following straw incorporation, such as phytotoxic levels of organic acids produced by the anaerobic decomposition of straw which negatively affects rice seedlings (Shan et al., 2008), but this would need further investigation. We observed less or no influence of mineral fertilizer application on rice yield. The sites surveyed in this study are inherently deficient in NPK levels (Saito et al., 2019) and the suboptimal crop management practices masked the positive impact of the small quantities of fertilizers applied. Further, fertilizer application to off-season crops and straw incorporation induced temporary $\mathrm{N}$ immobilization and organic acids production by anaerobic decomposition could negatively impacted the rice yields (Shan et al., 2008). Hence, introduction of good agricultural practices is essential in order to have good fertilizer response and site-specific information on most important good agricultural practices can be incorporated into RiceAdvice. Further, validation of the above findings through field trials are essential rather than relying solely on field surveys.

\section{CONCLUSION}

Across sites in Eastern and Southern Africa, the average rice yields ranged between 1.8 and $4.3 \mathrm{t} \mathrm{ha}^{-1}$ and the estimated yield gap ranged between 0.8 and $3.4 \mathrm{tha}^{-1}$. The large yield gaps observed here were due to variation in crop management practices followed by the farmers. The most important crop management practice that contributed to the observed yield variability were straw management, weeding frequency, growth duration of the variety, extent of weed cover, fertilizer (mineral and organic) application frequency, levelling and iron toxicity. Importance of these factors were site, year and production environment specific. Extending the crop duration by one day increased the yield by $0.05 \mathrm{t} \mathrm{ha}^{-1}$. Protecting the crop from grain feeding birds increased the yield by $1.44 \mathrm{t} \mathrm{ha}^{-1}$ in Fogera, Ethiopia. At Kahama in Tanzania good land levelling increased the yield by $0.74 \mathrm{t} \mathrm{ha}^{-1}$. At Kilombero in Tanzania, compared to a weed-free crop, presence of weeds reduced the yield by 3.6 to $4.4 \mathrm{t} \mathrm{ha}^{-1}$. There is a high potential to increase rice yield levels and reduce the current yield gaps on rice farms in Eastern and Southern Africa. Significant advancements can be made by improving crop, soil and weed management using existing, locally adapted technologies.

\section{ACKNOWLEDGEMENTS}

This is an output of the CGIAR Research Program Global Rice Science Partnership. Financial support for this study was provided by the African Development Bank as part of the project "Support to Agricultural Research for Development of Strategic Crops in Africa (SARD-SC)" and by the German Federal Ministry for Economic Cooperation and Development, commissioned by the Deutsche Gesellschaftfür Internationale Zusammenarbeit, through the project "East African Wetlands: Optimizing sustainable production for future food security (WETLANDS)". We thank Justin Djagba of AfricaRice for generating Figure. 1. We thank all farmers and extension personnel for their participation in the surveys.

\section{REFERENCES}

Adesina, A. A., Johnson, D. E., \& Heinrichs, E. A. (1994). Rice pests in the ivory coast, west africa: Farmers' perceptions and management strategies. International Journal of Pest Management, 40, 293-299. https://doi.org/10.1080/09670879409371902

Affholder, F., Poeydebat, C., Corbeels, M., Scopel, E., \& Tittonell, P. (2012). The yield gap of major food crops in family agriculture in the tropics: Assessment and analysis through field 
surveys and modelling. Field Crops Research. https://doi.org/10.1016/j.fcr.2012.10.021

AfricaRice. (2011). Boosting Africa's Rice Sector: A research for development strategy 2011 2020. Cotonou, Benin.

Akanvou, R., Becker, M., Chano, M., Johnson, D. E., Gbaka-Tcheche, H., \& Toure, A. (2000). Fallow residue management effects on upland rice in three agroecological zones of West Africa. Biology and Fertility of Soils, 31, 501-507. https://doi.org/10.1007/s003740000199

Audebert, a., \& Fofana, M. (2009). Rice Yield Gap due to Iron Toxicity in West Africa. Journal of Agronomy and Crop Science, 195, 66-76. https://doi.org/10.1111/j.1439037X.2008.00339.x

Balasubramanian, V., Sie, M., Hijmans, R. J., \& Otsuka, K. (2007). Increasing rice production in Sub-Saharan Africa: Challenges and opportunities. Advances in Agronomy, 94, 55-132. https://doi.org/10.1016/S0065-2113(06)94002-4

Becker, M., \& Asch, F. (2005). Iron toxicity in rice - Conditions and management concepts. Journal of Plant Nutrition and Soil Science, 168, 558-573. https://doi.org/10.1002/jpln.200520504

Bouman, B. A. M., Humphreys, E., Tuong, T. P., \& Barker, R. (2007). Rice and Water. Advances in Agronomy, 92(04), 187-237. https://doi.org/10.1016/S0065-2113(04)92004-4

Breiman, L. (2001). Random forests. Machine Learning, 45, 5-32.

Bruelle, G., Naudin, K., Scopel, E., Domas, R., Rabeharisoa, L., \& Tittonell, P. (2014). Short-to mid-term impact of conservation agriculture on yield variability of upland rice: Evidence from farmer's fields in madagascar. Experimental Agriculture, (May), 1-19. https://doi.org/10.1017/S0014479714000155

CARD. (2018). NRDS (National Rice Development Strategy) Task Force Reports. Coalition for African Rice Development. Retrieved 12 December 2018, from https://riceforafrica.net/index.php/nrds-page

Castellanos-Navarrete, A., Tittonell, P., Rufino, M. C., \& Giller, K. E. (2015). Feeding, crop residue and manure management for integrated soil fertility management-A case study from Kenya. Agricultural Systems, 134(March 2015), 24-35. Retrieved from http://www.sciencedirect.com/science/article/pii/S0308521X14000316

Cobo, J. G., Dercon, G., \& Cadisch, G. (2010). Nutrient balances in African land use systems across different spatial scales: A review of approaches, challenges and progress. Agriculture Ecosystems \& Environment, 136(1-2), 1-15.

Corbeels, M., Graaff, J. De, Hycenth, T., Penot, E., Baudron, F., Naudin, K., ... Solomon, I. (2014). Understanding the impact and adoption of conservation agriculture in Africa : A multi-scale analysis. 'Agriculture, Ecosystems and Environment', 187, 155-170. https://doi.org/10.1016/j.agee.2013.10.011

HarvestChoice. (2009). AEZ Tropical (5-class). International Food Policy Research Institute, Washigton DC, and University of Minnesota, St. Paul, MN. http://harvestchoice.org/node/4996.

De Mey, Y., Demont, M., \& Diagne, M. (2012). Estimating Bird Damage to Rice in Africa: Evidence from the Senegal River Valley. Journal of Agricultural Economics, 63, 175-200. https://doi.org/10.1111/j.1477-9552.2011.00323.x

Defoer, T., Wopereis, M. C. S., Jones, M. P., Lançon, F., Erenstein, O., \& Guei, R. G. (2004). Rice-based production systems for food security and poverty alleviation in sub-Saharan Africa. International Rice Commission Newsletter, 53(January), 85-96.

Diagne, A., Alia, D. Y., Amovin-assagba, E., Wopereis, M. C. S., Saito, K., \& Nakelse, T. (2013). Farmer Perceptions of the Biophysical Constraints to Rice Production in Sub-Saharan Africa, and Potential Impact of Research. In M. C. S. Wopereis, D. E. Johnson, N. Ahmadi, E. Tollens, \& A. Jalloh (Eds.), Realizing Africa's Rice Promise (pp. 46-68). CABI.

Diagne, M., Demont, M., Seck, P. A., \& Diaw, A. (2012). Self-sufficiency policy and irrigated 
rice productivity in the Senegal River Valley. Food Security, 5, 55-68.

https://doi.org/10.1007/s12571-012-0229-5

Dingkuhn, M., \& Asch, F. (1999). Phenological responses of Oryza sativa, O. glaberrima and inter-specific rice cultivars on a toposquence in West Africa. Euphytica, 110, 109-126.

Dobermann, A., \& Fairhurst, T. (2000). Rice: Nutrient Disorders \& Nutrient Management. Potash $\&$ Phosphate Institute (PPI), Potash \& Phosphate Institute of Canada (PPIC) and International Rice Research Institute (IRRI).

Dramé, K. N., Manneh, B., \& Ismail, A. M. (2013). Rice Genetic Improvement for Abiotic Stress Tolerance in Africa. In M. C. S. Wopereis, D. E. Johnson, N. Ahmadi, E. Tollens, \& A. Jalloh (Eds.), Realizing Africa's Rice Promise (pp. 144-160). CABI.

FAO. (2018). FAO database. Retrieved 17 December 2018, from http://faostat.fao.org/default.aspx

Haefele, S. M., Nelson, A., \& Hijmans, R. (2014). Soil quality and constraints in global rice production. Geoderma, 235-236, 250-259. https://doi.org/10.1016/j.geoderma.2014.07.019

Haefele, S. M., Saito, K., Diaye, K. M. N., Mussgnug, F., Nelson, A., \& Wopereis, M. C. S. (2013). Increasing Rice Productivity through Improved Nutrient Use in Africa. In M. C. S. Wopereis, D. E. Johnson, N. Ahmadi, E. Tollens, \& A. Jalloh (Eds.), Realizing Africa's Rice Promise (pp. 250-264). CABI. Retrieved from http://www.africarice.org/publications/rice_promise/Chap20 9781845938123.pdf

Johnson, J.-M., Rodenburg, J., Tanaka, A., Senthilkumar, K., Ahouanton, K., Dieng, I., ... Saito, K. (2018). Farmers' perceptions on mechanical weeders for rice production in sub-Saharan Africa. Experimental Agriculture, 1-15. https://doi.org/10.1017/S001447971700059X

Kijoji, A. A., Nchimbi-msolla, S., Kanyeka, Z. L., Klassen, S. P., Serraj, R., \& Henry, A. (2012). Water extraction and root traits in Oryza sativa $x$ Oryza glaberrima introgression lines under different soil moisture regimes. Functional Plant Biology, 1-13. Retrieved from http://dx.doi.org/10.1071/FP12163

Lobell, D. B., Cassman, K. G., \& Field, C. B. (2009). Crop Yield Gaps: Their Importance , Magnitudes , and Causes Crop Yield Gaps : Their Importance, Magnitudes , and Causes. Annual Review of Environment and Resources, 34, 1-26. https://doi.org/10.1146/annurevfienviron.041008.093740

Matsumoto, N., Paisancharoen, K., \& Ando, S. (2010). Effects of changes in agricultural activities on the nitrogen cycle in Khon Kaen Province, Thailand between 1990-1992 and 2000-2002. Nutrient Cycling In Agroecosystems, 86, 79-103.

Meertens, H. C. C., Ndege, L. J., \& Lupeja, P. M. (1999). The cultivation of rainfed, lowland rice in Sukumaland, Tanzania . Agriculture Ecosystems \& Environment, 76, 31-45.

Nhamo, N., Rodenburg, J., Zenna, N., Makombe, G., \& Luzi-Kilhupi, A. (2014). Narrowing the rice yield gap in East and Southern Africa: Using and adapting existing technologies. Agricultural Systems, 131, 45-55. https://doi.org/10.1016/j.agsy.2014.08.003

Niang, A., Becker, M., Ewert, F., Dieng, I., Gaiser, T., Tanaka, A., ... Saito, K. (2017). Variability and determinants of yields in rice production systems of West Africa. Field Crops Research, 207. https://doi.org/10.1016/j.fcr.2017.02.014

Niang, A., Becker, M., Ewert, F., Tanaka, A., Dieng, I., \& Saito, K. (2018). Yield variation of rainfed rice as affected by field water availability and $\mathrm{N}$ fertilizer use in central Benin. Nutrient Cycling in Agroecosystems, 110, 293-305. https://doi.org/10.1007/s10705-0179898-y

Nie, L., Peng, S., Chen, M., Shah, F., Huang, J., Cui, K., \& Xiang, J. (2012). Aerobic rice for water-saving agriculture. A review. Agronomy for Sustainable Development, 32, 411-418. https://doi.org/10.1007/s13593-011-0055-8

Onaga, G., Egdane, J., Edema, R., \& Abdelbagi, I. (2013). Morphological and Genetic Diversity Analysis of Rice Accessions ( Oryza sativa L .) Differing in Iron Toxicity Tolerance. Journal 
of Crop Science and Biotechnology, 1, 53-62.

Poussin, J. ., Wopereis, M. C. ., Debouzie, D., \& Maeght, J. (2003). Determinants of irrigated rice yield in the Senegal River valley. European Journal of Agronomy, 19, 341-356.

https://doi.org/10.1016/S1161-0301(02)00078-3

Prasad, R., Shivay, Y.S., Kumar, D. (2017). Current Status, Challenges, and Opportunities in Rice Production, in: Rice Production Worldwide. Springer International Publishing, Cham, pp. 132. https://doi.org/10.1007/978-3-319-47516-5_1.

R Development Core Team. (2018). R: A language and environment for statistical computing. R Foundation for Statistical Computing. Vienna, Austria.

Raboin, L., Randriambololona, T., Radanielina, T., Ramanantsoanirina, A., Ahmadi, N., \& Dusserre, J. (2014). Upland rice varieties for smallholder farming in the cold conditions in Madagascar's tropical highlands. Field Crops Research, 169, 11-20. https://doi.org/10.1016/j.fcr.2014.09.006

Rodenburg, J., Demont, M., Sow, A., \& Dieng, I. (2014). Bird, weed and interaction effects on yield of irrigated lowland rice. Crop Protection, 66, 46-52. https://doi.org/10.1016/j.cropro.2014.08.015

Rodenburg, J., Demont, M., Zwart, S. J., \& Bastiaans, L. (2016). Parasitic weed incidence and related economic losses in rice in Africa. Agriculture, Ecosystems and Environment, 235, 306-317. https://doi.org/10.1016/j.agee.2016.10.020

Rodenburg, J., \& Johnson, D. (2009). Weed Management in Rice-Based Cropping Systems in Africa. Advances in Agronomy, 103, 149-218. https://doi.org/10.1016/S00652113(09)03004-1

Rodenburg, J., Johnson, J. M., Dieng, I., Senthilkumar, K., Vandamme, E., Akakpo, C., ... Saito, K. (2019). Status quo of chemical weed control in rice in sub-Saharan Africa. Food Security. https://doi.org/10.1007/s12571-018-0878-0

Rodenburg, J., Saito, K., Irakiza, R., Makokha, D. W., Onyuka, E. A., \& Senthilkumar, K. (2015). Labor-Saving Weed Technologies for Lowland Rice Farmers in sub-Saharan Africa. Weed Technology, 29, 751-757. https://doi.org/10.1614/WT-D-15-00016.1

Saito, K., Diack, S., Dieng, I., Ndiaye, M.K. (2015). On-farm testing of a nutrient management decision-support tool for rice in the Senegal River valley. Computers and Electronics in Agriculture 116, 36-44. https://doi.org/10.1016/j.compag.2015.06.008

Saito, K., Dieng, I., Toure, A. A., Somado, E. A., \& Wopereis, M. C. S. (2015). Rice yield growth analysis for 24 African countries over 1960-2012. Global Food Security, 5, 62-69. https://doi.org/10.1016/j.gfs.2014.10.006Saito, K., Nelson, A., Zwart, S. J., Niang, A., Sow, A., Yoshida, H., \& Wopereis, M. C. S. (2013). Towards a Better Understanding of Biophysical Determinants of Yield Gaps and the Potential for Expansion of the Rice Area in Africa. In M. C. S. Wopereis, D. E. Johnson, N. Ahmadi, E. Tollens, \& A. Jalloh (Eds.), Realizing Africa's Rice Promise (pp. 188-203). CABI. Retrieved from file://C:/AfricaRice/Literature/Literature_General/Chap20 9781845938123.pdf

Saito, K., Oort, P. Van, Dieng, I., Johnson, J., Niang, A., Ahouanton, K., ... David Nanfumba. (2017). Yield gap analysis towards meeting future rice demand. In Achieving sustainable cultivation of rice Volume 2: Cultivation, pest and disease management (pp. 157-182). Burleigh Dodds Science Publishing, Cambridge, UK.

Saito, K., Sharma, S. (2018). e-Agriculture Promising Practice: Rice Crop Manager and RiceAdvice: Decision tools for rice crop management. http://www.fao.org/publications/card/en/c/I9039EN

Saito, K., Vandamme, E., Johnson, J., Tanaka, A., Senthilkumar, K., Dieng, I., ... Wopereis, M. C. S. (2019). Yield-limiting macronutrients for rice in sub-Saharan Africa. Geoderma, 338(June 2018), 546-554. https://doi.org/10.1016/j.geoderma.2018.11.036

Savary, S., \& Castilla, N. P. (2009). A survey portfolio to characterize yield-reducing factors in 
rice. International Rice Research Institute, Los Baños, Philippines.

Sekiya, N., Tomitaka, M., Oizumi, N., Assenga, A. N., \& Jacob, M. K. (2015). Farmer-to-Farmer

Extension Facilitated by Agricultural Training Institutions: A Case of NERICA

Dissemination in Tanzania. Plant Production Science, 18, 398-406.

https://doi.org/10.1626/pps.18.398

Senthilkumar, K., Bindraban, P. S., Thiyagarajan, T. M., de Ridder, N., \& Giller, K. E. (2008).

Modified rice cultivation in Tamil Nadu, India: Yield gains and farmers' (lack of) acceptance. Agricultural Systems, 98, 82-94.

Senthilkumar, K., Tesha, B. J., Mghase, J., \& Rodenburg, J. (2018). Increasing paddy yields and improving farm management: results from participatory experiments with good agricultural practices (GAP) in Tanzania. Paddy and Water Environment, 16, 749-766.

https://doi.org/10.1007/s10333-018-0666-7

Shan Y., Cai Z., Han Y., Johnson S.E., Buresh R.J. (2008). Organic acid accumulation under flooded soil conditions in relation to the incorporation of wheat and rice straws with different C:N ratios. Soil Science and Plant Nutrition 54, 46-56. https://doi.org/10.1111/j.1747$\underline{0765.2007 .00218 . \mathrm{x}}$

Sheldrick, W. F., Syers, J. K., \& Lingard, J. (2002). A conceptual model for conducting nutrient audits at national, regional, and global scales. Nutrient Cycling In Agroecosystems, 62, 6172.

Stoorvogel, J. J., \& Smaling, E. M. A. (1998). Research on soil fertility decline in tropical environments: integration of spatial scales. Nutrient Cycling in Agroecosystems, 50, 151-158.

Stuart, A. M., Pame, A. R. P., Silva, J. V., Dikitanan, R. C., Rutsaert, P., Malabayabas, A. J. B., ... Singleton, G. R. (2016). Yield gaps in rice-based farming systems: Insights from local studies and prospects for future analysis. Field Crops Research, 194, 43-56.

https://doi.org/10.1016/j.fcr.2016.04.039

Tanaka, A., Johnson, J.-M., Senthilkumar, K., Akakpo, C., Segda, Z., Yameogo, L. P., ... Saito, K. (2017). On-farm rice yield and its association with biophysical factors in sub-Saharan Africa. European Journal of Agronomy, 85, 1-11. https://doi.org/10.1016/j.eja.2016.12.010

Tanaka, A., Saito, K., Azoma, K., \& Kobayashi, K. (2013). Factors affecting variation in farm yields of irrigated lowland rice in southern-central Benin. European Journal of Agronomy, 44, 46-53. https://doi.org/10.1016/j.eja.2012.08.002

Thiyagarajan, T. M., Velu, V., Ramasamy, S., Durgadevi, D., Govindarajan, K., Priyadarshini, R., ... Bindraban, P. S. (2002). Effects of SRI practices on hybrid rice performance in Tamil Nadu, India. In B. Bouman, H. Hengsdijk, B. Hardy, P. Bindraban, T. Tuong, \& J. Ladha (Eds.), Water-wise rice production. Proceedings of the International Workshop on Waterwise Rice Production, 8-11 April 2002, Los Baños, Philippines (pp. 119-127). International Rice Research Institute, Los Baños (Philippines).

van Ittersum, M. K., \& Rabbinge, R. (1997). Concepts in production ecology for analysis and quantification of agricultural input-output combinations. Field Crops Research, 52, 197-208. https://doi.org/10.1016/S0378-4290(97)00037-3

van Ittersum, M. K., van Bussel, L. G. J., Wolf, J., Grassini, P., van Wart, J., Guilpart, N., ... Cassman, K. G. (2016). Can sub-Saharan Africa feed itself? Proceedings Of The National Academy Of Sciences Of The United States Of America, 113, 14964-14969. https://doi.org/10.1073/pnas.1610359113

van Oort, P. A. J., Saito, K., Tanaka, A., Amovin-Assagba, E., Van Bussel, L. G. J., van Wart, J., ... Wopereis, M. C. S. (2015). Assessment of rice self-sufficiency in 2025 in eight African countries. Global Food Security, 5, 39-49. https://doi.org/10.1016/j.gfs.2015.01.002

Vandamme, E., Ahouanton, K., Mwakasege, L., Mujuni, S., Mujawamariya, G., Kamanda, J., ... Saito, K. (2018). Phosphorus micro-dosing as an entry point to sustainable intensification of 
rice systems in sub-Saharan Africa. Field Crops Research.

https://doi.org/10.1016/j.fcr.2018.02.016

Verhofstadt, E., \& Maertens, M. (2014). Smallholder cooperatives and agricultural performance in Rwanda: do organizational differences matter? Agricultural Economics, 45, 1-14.

https://doi.org/10.1111/agec.12128

Zenna, N., Senthilkumar, K., Sie, M. (2017). Rice Production in Africa, in: Rice Production Worldwide. Springer International Publishing, Cham, pp. 117-135.

https://doi.org/10.1007/978-3-319-47516-5_5.

\section{Figures}

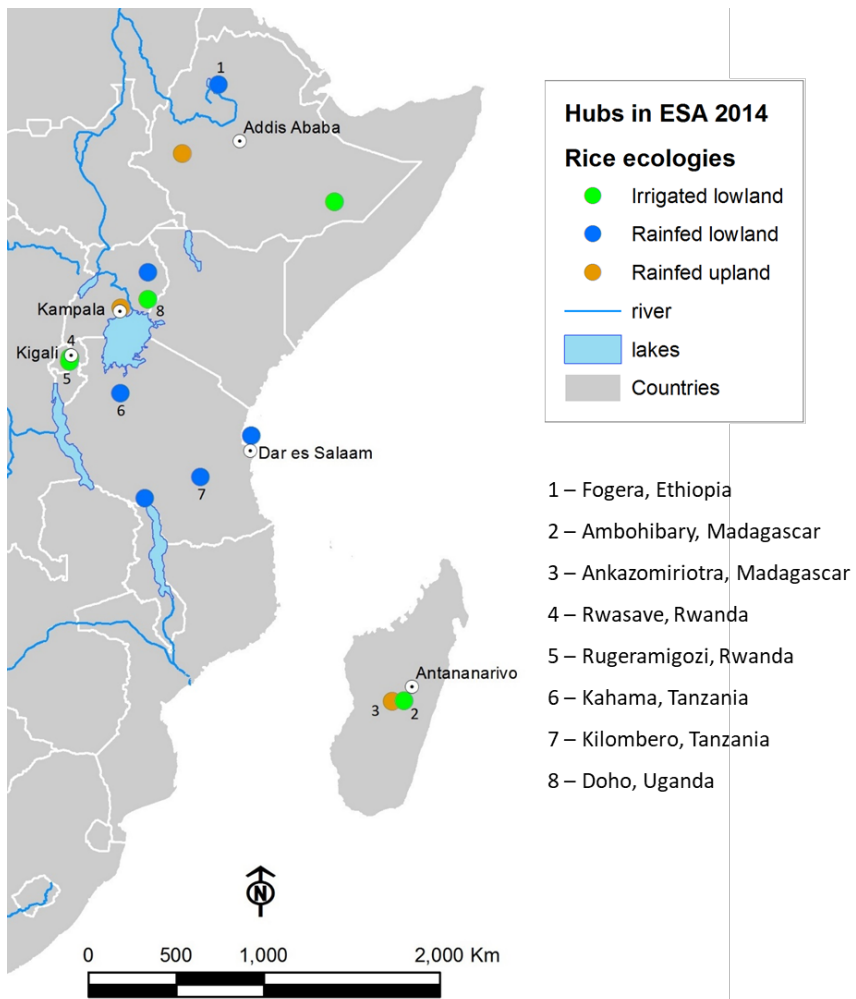

FIGURE 1. Map showing the location of the rice sector development hubs (sites) identified in the ESA countries. The present study was conducted only in the numbered ( 1 to 8$)$ sites. 

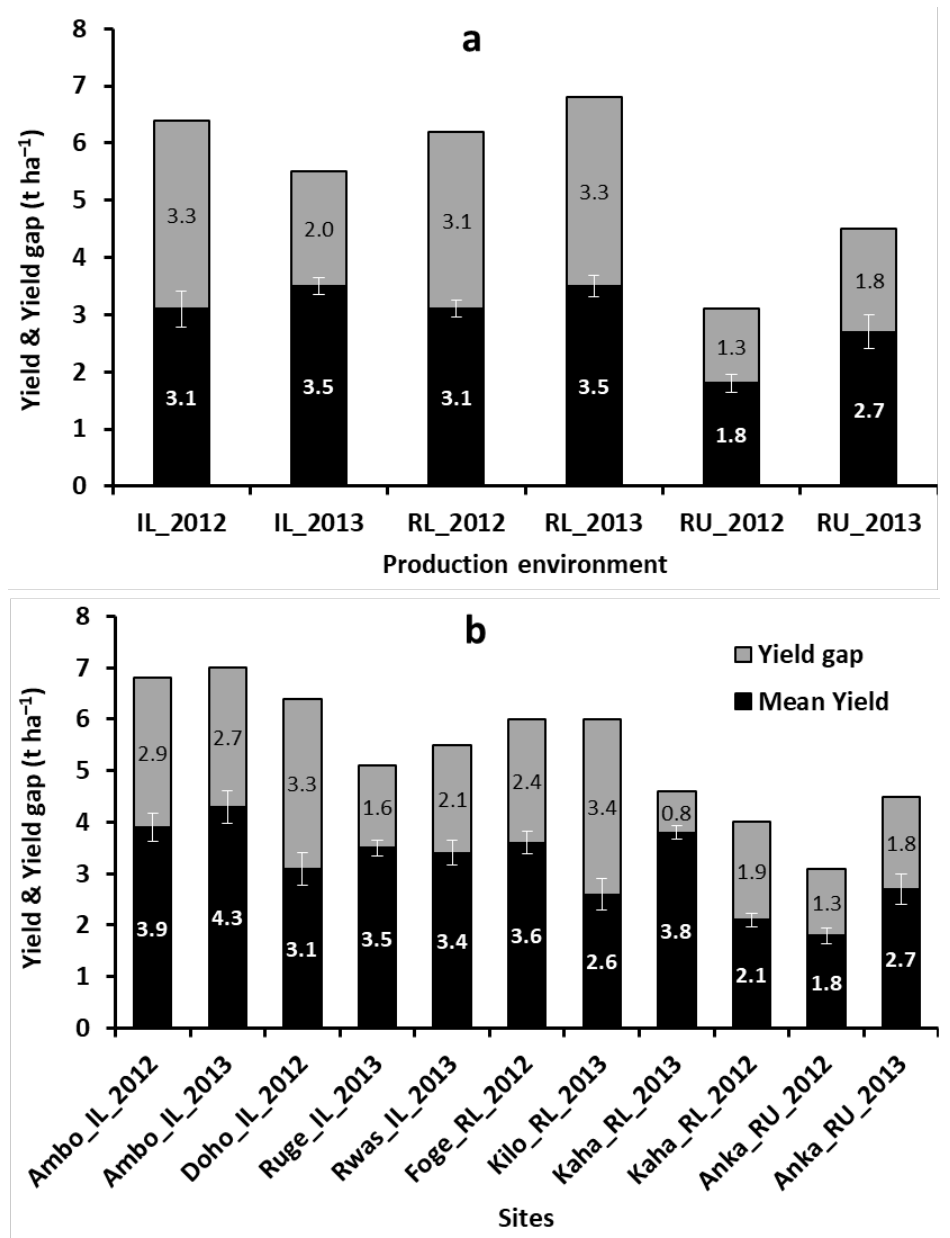

FIGURE 2. Mean rice yield and yield gap $\left(\mathrm{t} \mathrm{ha}^{-1}\right)$ at production environment (a) and site (b) level in the five ESA countries. The error bars indicate the standard error. 


\section{Tables}

Table 1. Country, site, agro-ecological zone, site number (\#; refereeing to Figure 1), production environment $(\mathrm{IL}=$ irrigated lowland; $\mathrm{RL}=$ rainfed lowland; RU=rainfed upland) and the number of fields surveyed per hub per year

\begin{tabular}{|c|c|c|c|c|c|c|c|}
\hline Country & Site name & $\mathbf{A E Z} \mathbf{Z}^{\mathbf{a}}$ & Site \# & Production environment & 2012 & 2013 & Total \\
\hline Ethiopia & Fogera & Highlands & 1 & RL & 32 & 0 & 32 \\
\hline \multirow[t]{2}{*}{ Madagascar } & Ambohibary & Highlands & 2 & IL & 39 & 22 & 61 \\
\hline & Ankazomiriotra & Highlands & 3 & RU & 24 & 19 & 43 \\
\hline \multirow[t]{2}{*}{ Rwanda } & Rwasave & Highlands & 4 & IL & 0 & 50 & 50 \\
\hline & Rugeramigozi & Highlands & 5 & IL & 0 & 50 & 50 \\
\hline \multirow[t]{2}{*}{ Tanzania } & Kahama & Sub-humid & 6 & RL & 45 & 19 & 64 \\
\hline & Kilombero & Sub-humid & 7 & $\mathrm{RL}$ & 0 & 29 & 29 \\
\hline Uganda & Doho & Humid & 8 & IL & 28 & 0 & 28 \\
\hline
\end{tabular}

${ }^{a}$ AEZ indicates agro-ecological zone (5 classes) for sub-Saharan Africa published by HarvestChoice (2009) following the methodology of the Food and Agricultural Organization of the United Nations and International Institute for Applied Systems Analysis. 
Table 2. Method of straw management, land preparation and crop establishment practiced (in \% fields surveyed) in the study sites. The production environment ( $\mathrm{IL}=$ irrigated lowland; $\mathrm{RL}=$ rainfed lowland; $\mathrm{RU}=$ rainfed upland) presented in parenthesis.

\begin{tabular}{|c|c|c|c|c|c|c|c|c|c|}
\hline \multirow[b]{2}{*}{ Production practice (in \% fields surveyed) } & \multicolumn{2}{|l|}{ Madagascar } & \multicolumn{2}{|l|}{ Tanzania } & \multirow{2}{*}{$\begin{array}{l}\text { Uganda } \\
\text { *Doho (IL) }\end{array}$} & \multirow{2}{*}{$\begin{array}{l}\text { Ethiopia } \\
\text { Fogera } \\
\text { (RL) } \\
\end{array}$} & \multicolumn{2}{|l|}{ Rwanda } & \multirow{2}{*}{$\begin{array}{l}\text { All } \\
\text { sites } \\
\text { (mean) }\end{array}$} \\
\hline & $\begin{array}{l}\text { Ambohiba } \\
\text { ry (IL) }\end{array}$ & $\begin{array}{l}\text { Ankazomiri } \\
\text { otra (RU) }\end{array}$ & $\begin{array}{l}\text { Kahama } \\
\text { (RL) }\end{array}$ & $\begin{array}{l}\text { Kilombero } \\
\text { (RL) }\end{array}$ & & & $\begin{array}{l}\text { Rwasave } \\
\text { (IL) }\end{array}$ & $\begin{array}{l}\text { Rugeramigo } \\
\text { zi (IL) }\end{array}$ & \\
\hline \multicolumn{10}{|l|}{ Straw management } \\
\hline Removing from the field & 66 & 72 & 2 & 0 & 7 & 81 & 72 & 96 & 49 \\
\hline Burning in the field & 0 & 0 & 6 & 69 & 25 & 3 & 0 & 0 & 13 \\
\hline Animal feeding in the field & 5 & 0 & 75 & 7 & 0 & 16 & 4 & 0 & 13 \\
\hline Mulching in the field & 0 & 9 & 8 & 3 & 0 & 0 & 0 & 0 & 3 \\
\hline Incorporation into the soil in the field & 30 & 19 & 9 & 21 & 32 & 0 & 24 & 4 & 17 \\
\hline \multicolumn{10}{|l|}{ Tillage method } \\
\hline Animal & 31 & 95 & 100 & 24 & 29 & 100 & 0 & 0 & 47 \\
\hline Manual & 69 & 5 & 0 & 0 & 36 & 0 & 100 & 100 & 39 \\
\hline Mechanical & 0 & 0 & 0 & 76 & 0 & 0 & 0 & 0 & 9 \\
\hline \multicolumn{10}{|l|}{ Bunding } \\
\hline Yes & 100 & 7 & 100 & 0 & 100 & 100 & 100 & 100 & 76 \\
\hline No & 0 & 93 & 0 & 100 & 0 & 0 & 0 & 0 & 24 \\
\hline \multicolumn{10}{|l|}{ Land Levelling } \\
\hline Not leveled & 0 & 40 & 8 & 28 & 0 & 0 & 0 & 0 & 9 \\
\hline Poorly leveled & 2 & 28 & 78 & 34 & 25 & 100 & 50 & 50 & 46 \\
\hline Well leveled & 98 & 33 & 14 & 38 & 71 & 0 & 50 & 50 & 44 \\
\hline \multicolumn{10}{|l|}{ Crop establishment method } \\
\hline Direct seeding & 11 & 100 & 22 & 86 & 0 & 100 & 0 & 0 & 40 \\
\hline Transplanting & 89 & 0 & 78 & 14 & 100 & 0 & 100 & 100 & 60 \\
\hline
\end{tabular}


Table 3. Weed infestation above and below rice canopy half-way the cropping season, weeding frequency and mechanical weeding practices (in $\%$ fields surveyed) observed in the study sites.

\begin{tabular}{|c|c|c|c|c|c|c|c|c|c|}
\hline \multirow[b]{2}{*}{ Percentage weed infestation } & \multicolumn{2}{|l|}{ Madagascar } & \multicolumn{2}{|l|}{ Tanzania } & Uganda & \multirow{2}{*}{$\begin{array}{l}\text { Ethiopia } \\
\text { Fogera } \\
\text { (RL) }\end{array}$} & \multicolumn{2}{|l|}{ Rwanda } & \multirow[b]{2}{*}{$\begin{array}{l}\text { All sites } \\
\text { (mean) }\end{array}$} \\
\hline & $\begin{array}{l}\text { Ambohiba } \\
\text { ry (IL) }\end{array}$ & $\begin{array}{l}\text { Ankazomiri } \\
\text { otra (RU) }\end{array}$ & $\begin{array}{l}\text { Kahama } \\
\text { (RL) }\end{array}$ & $\begin{array}{l}\text { Kilombero } \\
\text { (RL) }\end{array}$ & Doho (IL) & & $\begin{array}{l}\text { Rwasave } \\
\text { (IL) }\end{array}$ & $\begin{array}{l}\text { Rugerami } \\
\text { gozi (IL) }\end{array}$ & \\
\hline \multicolumn{10}{|c|}{ Weed infestation score below canopy ${ }^{I}$} \\
\hline $0:$ None & 0 & 0 & 9 & 3 & 11 & 3 & 8 & 2 & 5 \\
\hline 1: Low & 70 & 60 & 50 & 21 & 36 & 50 & 62 & 48 & 50 \\
\hline 2: Moderate & 28 & 33 & 22 & 45 & 36 & 38 & 10 & 38 & 31 \\
\hline 3: High & 2 & 7 & 19 & 31 & 18 & 9 & 20 & 12 & 15 \\
\hline \multicolumn{10}{|c|}{ Weed infestation score above canopy } \\
\hline 0 : None & 59 & 21 & 59 & 48 & 46 & 78 & 88 & 94 & 62 \\
\hline 1: Low & 39 & 77 & 33 & 48 & 29 & 19 & 4 & 6 & 32 \\
\hline 2: Moderate & 2 & 2 & 6 & 0 & 21 & 3 & 6 & 0 & 5 \\
\hline 3: High & 0 & 0 & 2 & 3 & 4 & 0 & 2 & 0 & 1 \\
\hline \multicolumn{10}{|l|}{ Weeding frequency ${ }^{2}$} \\
\hline 0 & 2 & 0 & 8 & 0 & 7 & 0 & 0 & 0 & 2 \\
\hline 1 & 0 & 14 & 73 & 97 & 68 & 3 & 10 & 18 & 35 \\
\hline 2 & 7 & 14 & 19 & 0 & 25 & 53 & 58 & 74 & 31 \\
\hline 3 & 21 & 56 & 0 & 3 & 0 & 41 & 32 & 6 & 20 \\
\hline$>3$ & 70 & 16 & 0 & 0 & 0 & 3 & 0 & 2 & 11 \\
\hline \multicolumn{10}{|l|}{ Mechanical weeding } \\
\hline Yes & 97 & 49 & 28 & 0 & 50 & 0 & 0 & 0 & 28 \\
\hline No & 3 & 51 & 72 & 100 & 50 & 100 & 100 & 100 & 72 \\
\hline
\end{tabular}

${ }^{1}$ None: no weeds observed; Low: Weed cover less than or equal to $10 \%$; Moderate: Weed cover above $10 \%$ and less than or equal to $30 \%$; High: Weed cover above $30 \%$

${ }^{2}$ Weeding frequency: $0=$ no weeding; $1=$ one intervention; $2=$ two interventions; $3=3$ interventions; $>3=$ more than three interventions. 
Table 4. Frequency of mineral and organic fertilizer application (\% fields surveyed) and rate of application $\left(\mathrm{kg} \mathrm{ha}^{-1}\right)$ as observed in the study sites.

\begin{tabular}{|c|c|c|c|c|c|c|c|c|c|}
\hline \multirow[b]{2}{*}{ Fertilizer application frequency and rate } & \multicolumn{2}{|l|}{ Madagascar } & \multicolumn{2}{|l|}{ Tanzania } & \multirow{2}{*}{$\begin{array}{l}\text { Uganda } \\
\text { Doho (IL) }\end{array}$} & \multirow{2}{*}{$\begin{array}{l}\text { Ethiopia } \\
\text { Fogera } \\
(\mathrm{RL}) \\
\end{array}$} & \multicolumn{2}{|l|}{ Rwanda } & \multirow{2}{*}{$\begin{array}{l}\text { All } \\
\text { sites } \\
\text { (mean) }\end{array}$} \\
\hline & $\begin{array}{l}\text { Ambohibary } \\
\text { (IL) }\end{array}$ & $\begin{array}{l}\text { Ankazomiriotra } \\
\text { (RU) }\end{array}$ & $\begin{array}{l}\text { Kahama } \\
(\mathrm{RL})\end{array}$ & $\begin{array}{l}\text { Kilombero } \\
\text { (RL) }\end{array}$ & & & $\begin{array}{l}\text { Rwasave } \\
\text { (IL) }\end{array}$ & $\begin{array}{l}\text { Rugeramigozi } \\
\text { (IL) }\end{array}$ & \\
\hline \multicolumn{10}{|l|}{ Frequency of fertilizer application (\%) } \\
\hline No mineral or organic fertilizer & 48 & 0 & 59 & 76 & 46 & 66 & 0 & 2 & 37 \\
\hline Mineral fertilizer only & 7 & 2 & 5 & 24 & 0 & 28 & 32 & 24 & 15 \\
\hline Organic fertilizer only & 33 & 77 & 17 & 0 & 50 & 6 & 0 & 2 & 23 \\
\hline Both mineral and organic fertilizer & 13 & 21 & 19 & 0 & 4 & 0 & 68 & 72 & 25 \\
\hline \multicolumn{10}{|l|}{ Mineral fertilizer application rate $\left(\mathrm{kg} \mathrm{ha}^{-1}\right)$} \\
\hline $\operatorname{Max} N$ & 40.4 & 26.9 & 55.0 & 46.9 & 1.5 & 156.2 & 108.1 & 157.4 & 74.1 \\
\hline Mean N & 4.8 & 2.1 & 9.2 & 11.3 & 0.1 & 11.2 & 45.2 & 22.3 & 13.3 \\
\hline Max P & 3.0 & 14.9 & 28.8 & 0 & 0 & 46.0 & 55.1 & 113.1 & 32.6 \\
\hline Mean P & 0.1 & 1.6 & 1.0 & 0 & 0 & 4.0 & 21.2 & 24.5 & 6.6 \\
\hline Max K & 2.2 & 10.9 & 0 & 0 & 0 & 0 & 118.2 & 40.7 & 21.5 \\
\hline Mean K & 0.1 & 1.2 & 0 & 0 & 0 & 0 & 25.6 & 10.7 & 4.7 \\
\hline
\end{tabular}


Table 5: Variety type, irrigation and drainage, biotic and abiotic constraints (in \% fields surveyed) observed in the study sites.

\begin{tabular}{|c|c|c|c|c|c|c|c|c|c|}
\hline \multirow[b]{2}{*}{$\begin{array}{l}\text { Production practice (in \% fields } \\
\text { surveyed) }\end{array}$} & \multicolumn{2}{|c|}{ Madagascar } & \multicolumn{2}{|l|}{ Tanzania } & \multirow{2}{*}{\begin{tabular}{|l|} 
Uganda \\
Doho (IL)
\end{tabular}} & \multirow{2}{*}{$\begin{array}{l}\text { Ethiopia } \\
\text { Fogera } \\
\text { (RL) }\end{array}$} & \multicolumn{2}{|l|}{ Rwanda } & \multirow{2}{*}{$\begin{array}{l}\text { All sites } \\
\text { (mean) }\end{array}$} \\
\hline & $\begin{array}{l}\text { Ambohib } \\
\text { ary (IL) }\end{array}$ & $\begin{array}{l}\text { Ankazomi } \\
\text { riotra } \\
\text { (RU) }\end{array}$ & $\begin{array}{l}\text { Kahama } \\
\text { (RL) }\end{array}$ & $\begin{array}{l}\text { Kilombero } \\
\text { (RL) }\end{array}$ & & & $\begin{array}{l}\text { Rwasave } \\
\text { (IL) }\end{array}$ & $\begin{array}{l}\text { Rugerami } \\
\text { gozi (IL) }\end{array}$ & \\
\hline Traditional & 100 & 12 & 88 & 62 & 64 & 100 & 96 & 98 & 77 \\
\hline Improved & 0 & 88 & 13 & 38 & 36 & 0 & 4 & 2 & 23 \\
\hline \multicolumn{10}{|l|}{ Irrigation system } \\
\hline Yes & 100 & 0 & 0 & 0 & 100 & 81 & 100 & 100 & 60 \\
\hline \multicolumn{10}{|l|}{ Drainage system } \\
\hline Yes & 100 & 5 & 0 & 0 & 100 & 88 & 100 & 100 & 62 \\
\hline No & 0 & 95 & 100 & 100 & 0 & 13 & 0 & 0 & 38 \\
\hline \multicolumn{10}{|l|}{ Bird control } \\
\hline Yes & 0 & 0 & 0 & 0 & 93 & 9 & 50 & 28 & 23 \\
\hline No & 100 & 100 & 100 & 100 & 7 & 91 & 50 & 72 & 77 \\
\hline \multicolumn{10}{|l|}{ Iron toxicity } \\
\hline No & 90 & 100 & 86 & 90 & 86 & 100 & 8 & 2 & 70 \\
\hline Mild & 10 & 0 & 13 & 10 & 11 & 0 & 10 & 4 & 7 \\
\hline Moderate & 0 & 0 & 2 & 0 & 4 & 0 & 10 & 2 & 2 \\
\hline Severe & 0 & 0 & 0 & 0 & 0 & 0 & 72 & 92 & 21 \\
\hline
\end{tabular}


Table 6 . The top- 5 crop management factors causing yield variability, in decreasing order of importance, per site (a) and per production environment (b) per year.

\begin{tabular}{|c|c|c|c|c|c|c|}
\hline $\begin{array}{l}\text { Site or Production } \\
\text { environment }\end{array}$ & Year & Factor 1 & Factor 2 & Factor 3 & Factor 4 & Factor 5 \\
\hline \multicolumn{7}{|l|}{ a) Site } \\
\hline \multirow[t]{2}{*}{ Ambohibary (IL) } & 2012 & Weeding frequency & Crop establishment method & Tillage method & Weeds above rice canopy & Weeds below rice canopy \\
\hline & 2013 & Crop duration & Weeds above rice canopy & Weeding frequency & Tillage method & Levelling \\
\hline \multirow[t]{2}{*}{ Ankazomiriotra (RU) } & 2012 & Straw management & $\begin{array}{l}\text { Mineral fertilizer application } \\
\text { frequency }\end{array}$ & $\mathrm{N}$ application & Weeds below rice canopy & Seed source \\
\hline & 2013 & $\begin{array}{l}\text { Weeds above rice } \\
\text { canopy }\end{array}$ & Weeding frequency & Weeds below rice canopy & Crop duration & Straw management \\
\hline Doho (IL) & 2012 & Crop duration & $\begin{array}{l}\text { Organic fertilizer application } \\
\text { frequency }\end{array}$ & Straw management & Bird control & Seed source \\
\hline Fogera (RL) & 2012 & Crop duration & Straw management & Bird control & Weeds below rice canopy & $\begin{array}{l}\text { Irrigation system } \\
\text { availability }\end{array}$ \\
\hline \multirow[t]{2}{*}{ Kahama (RL) } & 2012 & $\mathrm{P}$ application & Weeding frequency & $\begin{array}{l}\text { Organic fertilizer application } \\
\text { frequency }\end{array}$ & Weeds above rice canopy & $\begin{array}{l}\text { Mineral fertilizer } \\
\text { application frequency }\end{array}$ \\
\hline & 2013 & Levelling & Mechanical weeding & Cultivar choice & Weeding frequency & $\begin{array}{l}\text { Mineral fertilizer } \\
\text { application frequency }\end{array}$ \\
\hline Kilombero (RL) & 2013 & Iron toxicity & Crop duration & Crop establishment method & Weeds below rice canopy & Weeds above rice canopy \\
\hline Rugeramigozi (IL) & 2013 & Weeding frequency & Straw management & Iron toxicity & $\begin{array}{l}\text { Mineral fertilizer application } \\
\text { frequency }\end{array}$ & $\mathrm{N}$ application \\
\hline Rwasave (IL) & 2013 & Iron toxicity & Straw management & $\mathrm{N}$ application & $\begin{array}{l}\text { Organic fertilizer application } \\
\text { frequency }\end{array}$ & Levelling \\
\hline \multicolumn{7}{|c|}{ b) Production environment } \\
\hline \multirow[t]{2}{*}{ Irrigated lowland } & 2012 & Crop duration & $\begin{array}{l}\text { Organic fertilizer application } \\
\text { frequency }\end{array}$ & Straw management & Bird control & Seed source \\
\hline & 2013 & Straw management & Iron toxicity & Weeding frequency & Weeds below rice canopy & Levelling \\
\hline \multirow[t]{2}{*}{ Rainfed lowland } & 2012 & Weeding frequency & Straw management & Irrigation system availability & Tillage method & Crop establishment method \\
\hline & 2013 & Tillage method & Bunding & Crop establishment method & Weeds above rice canopy & Iron toxicity \\
\hline \multirow[t]{2}{*}{ Rainfed upland } & 2012 & Straw management & $\begin{array}{l}\text { Mineral fertilizer application } \\
\text { frequency }\end{array}$ & $\mathrm{N}$ application & Weeds below rice canopy & Seed source \\
\hline & 2013 & $\begin{array}{l}\text { Weeds above rice } \\
\text { canopy }\end{array}$ & Weeding frequency & Weeds below rice canopy & Crop duration & Straw management \\
\hline
\end{tabular}


Table 7. Degree of influence of selected production factors on yield variability per site per year.

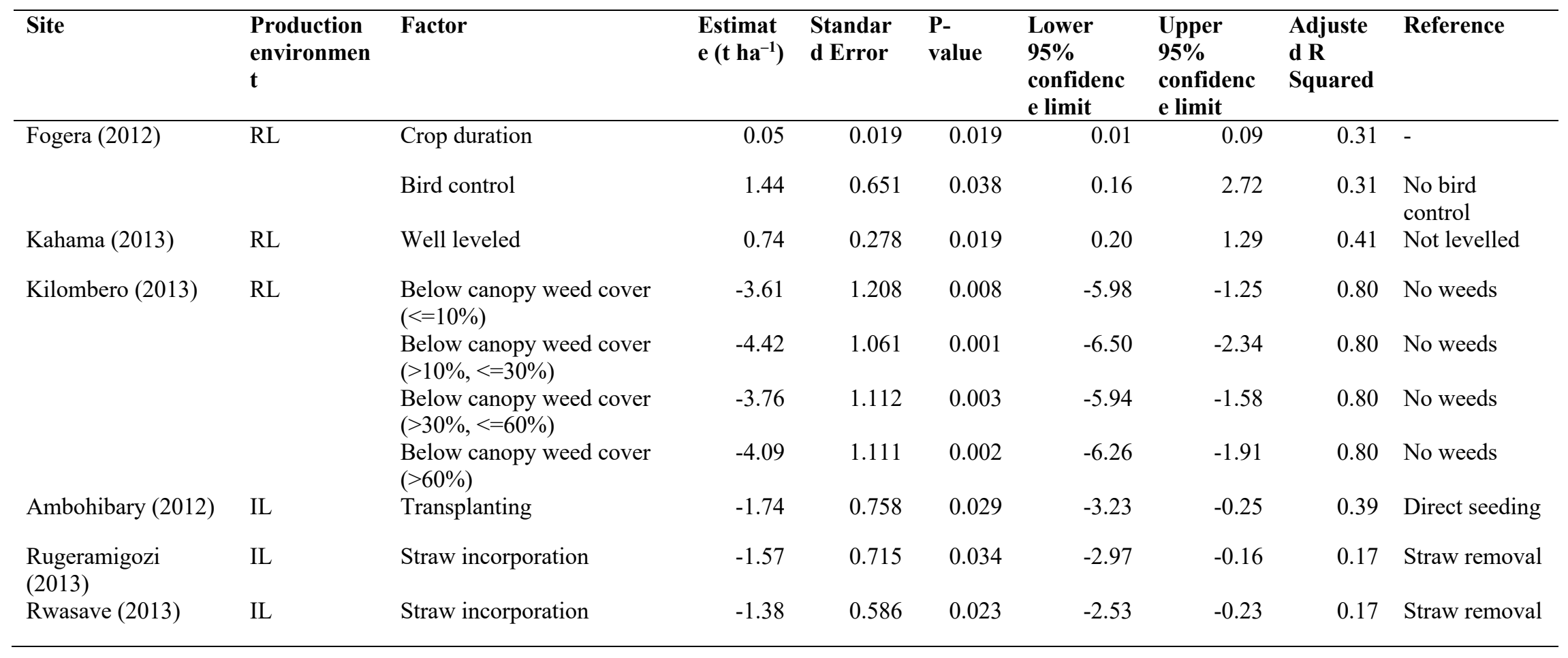

